Smyrnov Igor, Doctor of Sciences (Geography), Professor, Kyiv National Taras Shevchenko University Kyiv, Ukraine

ORCID: 0000-0002-6395-7251

\title{
SUSTAINABLE DEVELOPMENT OF INTERNATIONAL TOURISM BUSINESS IN OVERTOURISM CONDITIONS AS A GLOBAL IMPERATIVE
}

Considered issues of overtourism and urban tourism from logistical point of view in the aspect of tourism sustainable development. Substantiated problem of urban tourism logistics as a way of solving the problem of overtourism in cities. Revealed essence of complex logistic strategy of sustainable urban tourism development in the conditions of overtourism, which is based on four concepts: decentralization of tourism, reverse logistics, marketing impact on logistics and increased requirements to tourists safety problems. The first concept is based on the logistical organization of the tourist area of the city. The second concept involves an integrated approach to the utilization of the total amount of municipal waste, including tourist one. The third concept reflects how to use marketing to influence city tourist traffic. The fourth concept reflects the aggravation of the tourists safety problem in cities in the conditions of overtourism. In this context the experience of the Ukrainian city of Lviv has been explored.

Key words: sustainable development, overtourism, urban tourism, complex logistic strategy.

\section{Смирнов Ігор. Сталий розвиток міжнародного туристичного бізнесу в умовах овертуризму як глобального імперативу.}

Розглянуто питання овертуризму та міського туризму з логістичної точки зору в аспекті сталого розвитку туризму. Обтрунтовано проблему логістики міського туризму як спосіб вирімення проблеми овертуризму в містах. Розкрито сутність комплексної логістичної стратегії сталого розвитку міського туризму в умовах овертуризму, яка базується на чотирьох концепиіях: децентралізація туризму, зворотня логістика, маркетинговий вплив на логістику та підвищення вимог до проблем безпеки туристів. Перша концепиія трунтується на логістичній організації туристичної зони міста. Друга концепиія передбачає комплексний підхід до утилізаиії загальної кількості комунальних відходів, у тому числі туристичних. Третя концепція відображає, як використовувати маркетинг для впливу на туристичний трафік міста. Четверта конщепщія 
відображає загострення проблеми безпеки туристів у містах в умовах овертуризму. У изьому контексті досліджено досвід українського міста Львів.

Ключові слова: сталий розвиток, овертуризм, міський туризм, комплексна логістична стратегія.

Relevance of research topic. Quite recently, namely in 2017, a new term appeared in the professional tourism vocabulary and it was «overtourism» [3]. This term reflects the challenges of managing the growing tourist flows in urban districts and the impact of urban tourism on cities and their inhabitants. Today, half of the world's population lives in urban areas, and it is estimated that by 2050 this figure will reach $70 \%$. The growing number of tourists increases the consumption of natural and tourist resources of cities, exerts socio-cultural influence and growing pressure on urban infrastructure. Therefore, for urban tourism, the important task nowadays is to effectively manage the flows of tourists to ensure the positive effects of their visits to cities for both local residents and tourists themselves. Today tourism is one of the few sectors of the world economy, which is constantly growing, while ensuring socioeconomic development, employment, infrastructure development and export (foreign exchange) incomes.

Formulation of the problem. The growth of urban tourism leads to the emergence of diverse challenges for sustainable development and practices that minimize the negative impact of tourism in cities, in particular on the use of natural resources, socio-cultural impact, increasing infrastructure load and tourists mobility and concentration management. In recent years, these challenges have also been accompanied by an increase in the offer of accommodation for tourists in cities through the new virtual platforms of tourist service. As a result, the number of tourists in cities has grown to such an extent that there were cases of negative attitude of the local population towards tourists, in particular due to the phenomena of their excessive concentration, especially in the central districts of cities, excessive noise and waste, as well as other inconveniences related to tourists. The case even came to the protests of the local population against tourists in some cities and emergence of terms like «overtourism» and «tourismophobia» and their use in the media. Therefore, it is important, even critical, to ensure the coordination of the development of urban tourism with the development of cities in the world agenda. This is reminiscent of the «New UN Development Program», which points to 17 goals for sustainable development, with particular reference to Goal 11 «Make cities inclusive, safe, resilient and sustainable» [2].

Analysis of recent researches and publications. The analysis of recent researches and publications on the subject of the article revealed that in Ukraine this topic is practically unknown. Instead, some author's works are devoted to the problem of urban tourism sustainable development $[5 ; 6 ; 7]$. The relevance of the topic, that is considered in the article, is evidenced by a study that was performed at the request of 
UNWTO in 2017 «Overtourism? Understanding and Managing Urban Tourism Growth beyond Perceptions» [2].

Presenting main material. What does it mean under the name of overtourism and when did this term appear? In 2016, it was first introduced by the consulting company Skift, Inc. and was patented. This company provides information and marketing services to the global tourism and hospitality industry and works from 2012. The company immediately guided this term to urban tourism under the slogan: «Future of the world - cities. The future of tourism is in cities. The future of tourism -smart cities that are convenient for both tourists and locals. The development of smart cities leads to an era of tourist smart mobility» [4]. There are several definitions of this term. For example, universities - participants of the international project «Overtourism? Understanding and managing the development of urban tourism growth beyond perception» defined overtourism as «the negative impact of tourism on destination or its part that excessively affects perceived standard of living of citizens and tourists (due to deterioration in quality of tourism products provided)» [2].

Tourism is one of the most dynamic sectors of the economy of regions and cities. The urgent problems in this regard are the task of ensuring the sustainable development of urban tourism. This is especially true for the most popular destinations among tourists, including metropolitan and historic cities, which attract significant tourist flows. The latter means increase of tourist loading on cities tourism resource base, as well as on the entire urban economy, population, development and nature. In this context, solving problem of urban tourism sustainable development requires efforts consolidation of various scientific and practical branches, among which important place belongs to tourism logistics, studying the flow phenomena in tourism industry, highlighting tourist traffic as the main stream, and financial, informational, commodity, personnel, material flows as service ones (additional). The objective of tourism logistics in context of tourism industry sustainable development is to regulate the main flow (tourist traffic), that will ensure the conservation of tourism resource base in cities. This problem is now quite noticeable not only in cities - the world largest tourist centers, but also in Ukraine. This applies, for example, to Lviv, Kyiv, Odesa etc. The problem of tourist overloading in Lviv has especially been well known and that was reflected in author's publications [6;7]. Therefore, in our opinion, the development of a complex logistic strategy for the sustainable development of urban tourism in the conditions of overtourism is necessary. This strategy, developed by the author, is based on four concepts. First one is the concept of tourism decentralization, second one - the concept of reverse logistics, third - the concept of marketing impact on logistics, and fourth - the concept of increasing safety requirements for tourists (Fig.1). The first concept - concept of tourism decentralization - implies the need for an efficient logistic organization of the city tourist area (LO CTA). The main components of LO CTA are: 1) geologistical identification of tourism resource base; 2) logistic planning of tourist flows; 3) logistic design of tourist infrastructure; 
4) logistic design of supply chains for tourism infrastructure objects. The first component covers the geographical and logistical identification of city tourist resources. The second component is based on determining the size and structure of tourist flows and their respective needs. The third component involves the logistic design of tourist infrastructure networks to meet the needs of tourists. The fourth component involves the logistic design of supply chains to meet the needs of tourist infrastructure networks with logistics and transport components in their composition.

\begin{tabular}{|c|c|c|c|}
\hline & \multicolumn{2}{|c|}{$\begin{array}{l}\text { Logistic strategy of urban tourism sustainable development in } \\
\text { conditions of overtourism }\end{array}$} & hent in \\
\hline $\begin{array}{l}\text { Concept of tourist } \\
\text { decentralization }\end{array}$ & $\begin{array}{l}\text { Concept of } \\
\text { reverse } \\
\text { logistics }\end{array}$ & $\begin{array}{l}\text { Concept of } \\
\text { marketing impact } \\
\text { on logistics }\end{array}$ & $\begin{array}{l}\text { Concept of } \\
\text { increasing } \\
\text { requirements for } \\
\text { tourists safety }\end{array}$ \\
\hline $\begin{array}{l}\text { Main provisions: } \\
\text { - tourist unloading } \\
\text { of cities } \\
\text { downtowns; } \\
\text { - tourist loading on } \\
\text { other cities districts; } \\
\text { - taking into } \\
\text { account tourism } \\
\text { needs and creating } \\
\text { the appropriate } \\
\text { infrastructure; } \\
\text { - promotional and } \\
\text { marketing support; } \\
\text { - logistic support. }\end{array}$ & $\begin{array}{l}\text { Main provisions: } \\
\text { - awareness of } \\
\text { tourist's } \\
\text { "contribution" to } \\
\text { problem of } \\
\text { accumulation and } \\
\text { recycling of urban } \\
\text { waste; } \\
\text { - awareness of } \\
\text { importance and } \\
\text { necessity of logistic } \\
\text { approach in solving } \\
\text { problem of tourist } \\
\text { waste in cities; } \\
\text { - organization of } \\
\text { gathering, removal } \\
\text { and processing of } \\
\text { tourist and municipal } \\
\text { waste; } \\
\text { - creation of modern } \\
\text { waste recycling } \\
\text { enterprises with } \\
\text { efficient waste } \\
\text { processing }\end{array}$ & $\begin{array}{l}\text { Main provisions: } \\
\text { - promotion of } \\
\text { national priorities in } \\
\text { tourism; } \\
\text { - targeted marketing } \\
\text { of certain kinds of } \\
\text { tourism; } \\
\text { - restriction of } \\
\text { advertising and } \\
\text { marketing support for } \\
\text { unwanted kinds of } \\
\text { tourism (intimate } \\
\text { tourism etc.) in order } \\
\text { to reduce relevant } \\
\text { tourist flows }\end{array}$ & $\begin{array}{l}\text { Main provisions: } \\
\text { - development of } \\
\text { higher requirements } \\
\text { for tourists safety in } \\
\text { conditions of } \\
\text { overtourism, } \\
\text { especially in the } \\
\text { areas of their } \\
\text { residence and food; } \\
\text { - permanent safety } \\
\text { control of tourists' } \\
\text { accommodation, } \\
\text { especially in private } \\
\text { apartments; } \\
\text { - constant monitoring } \\
\text { of tourists food } \\
\text { safety, especially } \\
\text { with regard to } \\
\text { organization and } \\
\text { equipment of "street } \\
\text { food" points in the } \\
\text { most popular tourists } \\
\text { places }\end{array}$ \\
\hline
\end{tabular}

Fig. 1. Conceptual basis of complex logistic strategy of urban tourism sustainable development in conditions of overtourism (author's development according to [5; 6; 7]).

There are many other problems in city of Lviv, connected with overtourism, besides tourist congestion, among them - task of garbage removal from city's streets. In summer of 2016, after fire at Gribovychi landfill, Lviv did not know where to take out its waste, which volumes naturally grew with tourists number increasing. Not surprisingly, the tourist record of Lviv (2.6 million tourists in 2017 - the first place among Ukrainian cities) coincided with the «rubbish crisis» in this city. Thus, use of 
the second concept, that is, concept of reverse logistics, aims to ensure the complete recycling of the total amount of urban waste. Meanwhile the daily volume of waste in Lviv is 600 tons. Problem of urban waste in this city can be solved on the basis of two approaches - transport and logistical. Until recently the first approach prevailed. And only recently city leadership turned to the logistical approach, that is, to the use of «reverse» logistics.

The third concept - concept of marketing impact on logistics - reflects one more problematic aspect of overtourism, which is related with sharp increase in the number of tourists in Lviv (which was warned by American experts who helped to develop «Tourist concept of Lviv»): as soon as tourism will begin to develop dynamically, among the guests of the city there will be those who come for intimate services. The popular Italian edition «La Repubblica» has dedicated special article to contemporary sexual destinations of the world, among which along with Thailand, Brazil, Cambodia, Cuba, Bangladesh, Colombia and Bulgaria, Ukraine is also mentioned. Until recently, according to «La Repubblica», to cities of Ukraine, where there was intimate tourism, belonged Odesa, Kyiv and Kharkiv. Lviv has recently joined them, although before the World War II it was a service city with numerous hotels, restaurants, and casinos. One can ask, what's the connection with logistics here? The answer is the following: the purpose of logistics is to study the flows processes in the economy in order to optimize them. Economic flows (including flows of tourists) link together such components of the market as demand and supply. Production (supply) applies varied marketing and advertising technologies to attract consumers with their demand. On the other hand, as we know, if there is demand appropriate proposal will be as well. But if there is no supply and no it's marketing support, then demand will be reduced greatly or disappear altogether. Applying these considerations to the situation with intimate tourism in Lviv, one can predict that if there is no active advertising and promotions of proposals from the side of night clubs, gentleman clubs, strip-bars etc., then tourists-consumers flows of this «tour-product» will decrease significantly.

Finally, the fourth concept - increasing requirements for tourists safety-reflects the need to apply increased tourists safety requirements in conditions of overtourism. The main provisions of this concept include: a) the development of increased requirements for tourists safety in the conditions of overtourism, in particular in spheres of their residence and meal; b) permanent and strict security control of tourist accommodation, especially in private apartments; c) the same safety control of tourist food - consuming processes with special attention to street food organization and equipment in the most popular among tourists cities locations. Examples of ignoring the above provisions with the following tragic consequences, unfortunately, happened in Lviv in early 2019. So, in January a gas-cylinder in kebab-shop exploded because of improper exploitation (at Svoboda Avenue near the famous Lviv Opera House, one person died - the shop employee, but a lot of people were frightened, including 
tourists). The next tragic event, in January too, which led to the death of two Ukrainian tourists (from Kiev) from carbon monoxide, was connected with the hiring by them a private apartment with bad state of gas heating. And that was not the finish, as next tragic event happened in Odesa in august 2019 and it was connected with fire in «Tokio-Star» hotel (9 dead).

Conclusion. The dynamic development of urban tourism in the conditions of overtourism, which is currently observed in Lviv, causes a number of problems, including the tourist overloading, especially in their central and historical parts; the destruction of many historical and architectural objects and monuments; increase in the amount of urban waste, including tourist one; cases of intimate tourism; ignorance of the safety rules for tourists in areas of their residence and food with tragic consequences etc. The solution to most of these problems is possible while based on application of complex geologistics strategy, proposed by author. So the logistic approach, applied in «Concept of Tourism Decentralization in Lviv», should be extended to all other aspects of the city's tourism industry, including waste management, the use of advanced technologies and the attraction of national and international investments. These recommendations apply not only to Lviv but also to other major tourist centers of Ukraine - Kyiv, Kharkiv, Dnipro, Odesa etc.

\section{REFERENCES}

1. Ivanova E.V. 50 shades of Lviv. Novoye vremya. No. 19. 2018. P. 38-41 [in Russian].

2. Overtourism? Understanding and Managing Urban Tourism Growth beyond Perceptions. : UNWTO Library, 2018.URL: https: // www. e - unwto. org / doi.pdf

3. Rudneva M.G. World trends in tourism development in 2018. Actual problems of regional studies: Materials III International scientific-practical Internetconference. Lutsk: Vehza-Printing 2018, P. 49-53[in Ukrainian].

4. Skift Company. URL: https://skift.com/about/

5. Smyrnov I.G. Tourism logistics: text-book. K.: Znannya, 2009. $444 p$. [in Ukrainian].

6. Smyrnov I.G. Marketing of sustainable tourism: text-book. K .: PH Lira-K, 2019. 256 p. [in Ukrainian].

7. Smyrnov I.G. Comprehensive logistic approach to the sustainable development of urban tourism. Tourism and hospitality: state, problems, perspectives: mater. IV International scientific-practical. conference. Cherkasy: ChNU named after Bogdan Khmelnitsky; Publisher Tretyakov O. M., 2018. P. 80-85 [in Ukrainian]. 